
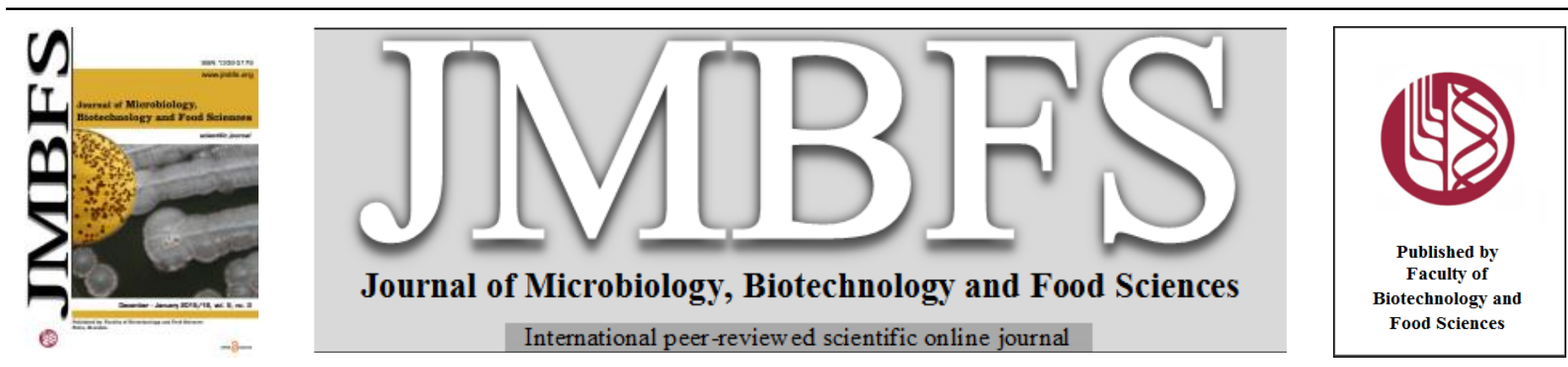

\title{
PURIFICATION AND CHARACTERIZATION OF HIGH POTENTIAL TYROSINASE FROM MACROFUNGI AND ITS APPLIANCE IN FOOD ENGINEERING
}

\author{
Kamal U. Zaidi, Ayesha S. Ali , Sharique A. Ali
}

Address(es): Dr. Ayesha Ali,

Department of Zoology \& Biotechnology, Saifia College of Science and Biotechnology Pharmacology Laboratory, Centre for Scientific Research \& Development, People's University Bhopal-462001, India.

*Corresponding author: drayeshariqali@yahoo.com

doi: 10.15414/jmbfs.2015/16.5.3.203-206

\section{ARTICLE INFO}

Received 10. 10. 2013

Revised 14. 7. 2014

Accepted 14. 8. 2015

Published 1. 12. 2015

\section{Regular article}

open $\partial_{\text {access }}$

\begin{abstract}
Tyrosinase (EC1.14.18.1) was extracted from oyster mushroom, Pleurotus ostreatus, using $100 \mathrm{mM}$ potassium phosphate buffer ( $\mathrm{pH}$ 5.8) containing $1 \mathrm{mM}$ of ethylenediaminetetra acetic acid. The enzyme was purified by ammonium sulfate precipitation, followed by Sephadex G-100 and diethylaminoethyl chromatography. The purified enzyme showed a specific activity of $46.4 \mathrm{U} / \mathrm{mg}$ with $20.3 \%$ yield. Sodium dodecyl sulphate-polyacrylamide gel electrophoresis showed single peptide chain with a molecular weight of $75 \mathrm{kDa}$. The enzyme has optimum activity on $\mathrm{pH} 6.0$ at $35^{\circ} \mathrm{C}$. The kinetics parameter with L-DOPA (3,4-dihydroxy-L-phenylalanine), with a $\mathrm{K}_{\mathrm{M}}$ of $0.119 \mathrm{mM}$ and $\mathrm{V}_{\max }$ of $2.97 \mathrm{mM}$. Thus, purified tyrosinase from P.ostreatus showed similarities with other tyrosinase sources. The results indicate that P.ostreatus can be a novel and better source of tyrosinase extraction due to its higher specific activity. The information offered here should help food industry in developing and using potential tyrosinase desirable efficacy and safety, and for improving food quality.
\end{abstract}

Keywords: Pleurotus ostreatus, Tyrosinase, Purification, Specific activity, Charaterization, Crosslinking enzyme, Extraction

\section{INTRODUCTION}

Food industries are in search for new biopolymers with special properties, as emulsifying, thickening agents, with low-calorie and low-fat foods. The uses of cross-linking enzyme represent the novel approach to improvement of the structure and texture of food by increasing the number of covalent bonds between its polymeric components, i.e. carbohydrates or proteins. Cross-linking enzyme such as tyrosinase, have been investigated in cereal, dairy, meat and fish processing (Buchert et al., 2010; Zaidi et al., 2013; Zaidi et al., 2014 a,b ). The modification of food proteins via crosslinking affects not only the texture of food but also their digestibility (Monogioudi et al., 2011). Cross-linking has also been reported to decrease the allergenicity of certain proteins (Stanic et al., 2010; Tantoush et al., 2011).

Different enzymes are used as hydrolyzing food biopolymers to improve product characteristics. Tyrosinase (EC1.14.18.1) is a oxidoreductase, catecholase, diphenol oxidase with bifunctional copper containing enzyme which performs a variety of functions ranging from pigmentation, defense to sclerotization and it has potential for use for application in the construction of a biosensor for detection of benzoate in food and beverages (Lee 1997; Ali et al 2011; Vania et al., 2013). Biosensors are devices that combine the specificity of biological reactions with suitable transducers electronics (Van Dorst $\boldsymbol{e t}$ al., 2010). It has advantages over the traditional techniques of analysis such as: portable, fast, selectivity, cost effective, detection without extensive sample pretreatment for greater applicability in food industries (Kotanen et al., 2012).

Selinheimo 2007, reported the use of tyrosinase, to generate food biopolymers with added functionalities or novel food structures from diverse raw materials. On reviewing the literature, it becomes evident that many species of mushrooms such as Lentinula edodes (Kanda et al., 1996), Amanita muscaria (Muller et al., 1996), Pycnoporus sanguineus (Halaouli et al., 2005) and Lentinula boryana (Faria et al., 2007) have been used to extract tyrosinase. The present study focused on purification and characterization of tyrosinase from $P$. ostretus for the first time. For the best of our knowledge the purified tyrosinase showed very high similarities to the other sources of tyrosinase.

\section{MATERIAL AND METHODS}

\section{Purification of tyrosinase from Pleurotus ostreatus mushroom extracts}

The extraction of tyrosinase from $P$. ostreatus was performed by the method of Haghbeen et al. (2004), with minor modifications. 300 grams of the fresh mushroom was homogenized with $300 \mathrm{ml}$ of potassium phosphate buffer (100 $\mathrm{mM}, \mathrm{pH} 5.8$ ) containing $1 \mathrm{mM}$ of EDTA in a warring blender. The suspension was stirred for $30 \mathrm{~min}$ at room temperature and filtered through a muslin cloth. This step was repeated twice and the filtrates were pooled together and centrifuged at $5000 \mathrm{rpm}$ for $30 \mathrm{~min}$ at $4^{\circ} \mathrm{C}$. The resulting supernatant was subjected to ammonium sulfate precipitation. Finely powdered ammonium sulfate was added to $75 \%$ saturation. The mixture was left for $2 \mathrm{hr}$ at $4^{\circ} \mathrm{C}$, followed by centrifugation at $1500 \times \mathrm{g} \mathrm{rpm}$ for $20 \mathrm{~min}$ at $4^{\circ} \mathrm{C}$. The supernatant was discarded; the resulting precipitate was dissolved in potassium phosphate buffer (100 mM, pH 5.8) and dialyzed overnight against the same buffer at $4{ }^{\circ} \mathrm{C}$. The dialyzed ammonium sulfate fraction was applied to a Sephadex G-100 column that was preequilibrated with a $100 \mathrm{mM}$ potassium phosphate buffer $\mathrm{pH} 6.0$. The protein elution was done with the same buffer at a flow rate of $5 \mathrm{ml} / \mathrm{min}$. The fractions were collected at $4^{\circ} \mathrm{C}$ and were assayed for protein content at $280 \mathrm{~nm}$ as well as for enzyme activity. The active fractions were pooled against the $100 \mathrm{mM}$ potassium phosphate buffer $\mathrm{pH}$ 6.0, and concentrated. The concentrated enzyme solution was applied to the column of diethylaminoethyl (DEAE) cellulose that was preequilibrated with a $100 \mathrm{mM}$ potassium phosphate buffer, $\mathrm{pH}$ 6.0. It was eluted with the $\mathrm{NaCl}$ gradient $(0.1-0.5 \mathrm{M})$ and $0.1 \mathrm{M}$ borate buffer, $\mathrm{pH}$ 6.0. The active fractions were collected, dialyzed and concentrated. The quality of the purified tyrosinase was evaluated by tyrosinase assay and SDS-PAGE.

\section{Assay for tyrosinase activity}

The tyrosinase activity was performed as reported by (Sung et al., 1992), in which the formation of the final dopachrome product was monitored spectrophotometrically at $475 \mathrm{~nm}$. The assay mixture containing tyrosinase was incubated for $5 \mathrm{~min}$ at $35^{\circ} \mathrm{C}$. At time zero, $1 \mathrm{ml}$ of L-DOPA (3,4-dihydroxy-Lphenylalanine, Sigma) concentration of $4 \mathrm{mg} / \mathrm{ml}$ spectrophotometrically, measuring conversion of L-DOPA to red colored oxidation product dopachrome. After incubation for additional $5 \mathrm{~min}$, the mixture was shaken again and a second reading was measured for 3 minutes. The change in absorbance was proportional 
to enzyme concentration. One unit of enzyme corresponded to the amount which catalyzed the transformation of $1 \mu \mathrm{mol}$ of substrate to product per min under above conditions and produced 1.35 changes in absorbance. Specific activity was expressed as enzyme unit per milligram of protein. The protein content of the enzyme was determined by the method of (Lowry et al., 1951) with bovine serum albumin as standard.

\section{Molecular weight determination}

Sodium dodecyl sulfate polyacrylamide gel electrophoresis (SDS-PAGE) was carried out in a 3-mm slab gel of $15 \%$ acrylamide in a Tris- $\mathrm{HCl}$ buffer $\mathrm{pH} 8.3$ containing $0.1 \%$ SDS. Molecular mass markers from 14.4 to $200 \mathrm{kDa}$ were used. The gels were stained with 0.025 Coomassie brilliant blue R-250.

\section{RESULTS AND DISCUSSION}

\section{Characterization of the crude extract}

The effects of $\mathrm{pH}$ on L-DOPA oxidation by the tyrosinase are shown in (Figure.1). The optimum activity of the enzyme on L-DOPA was observed at $\mathrm{pH}$ 6.0 whereas from $\mathrm{pH} 4.0$ to 5.0 , the enzyme had 20 to $30 \%$ activity. A similar result has been observed in Lentinula edodes(Kanda et al., 1996) and Lentinula boryana (Faria et al., 2007). On the other hand, optimum $\mathrm{pH}$ near neutral has been reported for tyrosinase of Portabella mushrooms (Fan et al., 2004) Agaricus bisporus (Gouzi et al., 2007) and Pycnoporus sanguineus (Halaouli et al., 2005) . The tyrosinase isolated sunflower plant remained fully active between $\mathrm{pH} 4.8$ to 7.9 after 20-hour exposure to buffers of different $\mathrm{pH}$ at $4^{\circ} \mathrm{C}$. Sang et al. (2005), have reported that in case of recombinant human tyrosinase, the optimum $\mathrm{pH}$ was 7.5 which as compared to that of presently studied Pleurotus ostreatus, is quite low, being 6.0 .

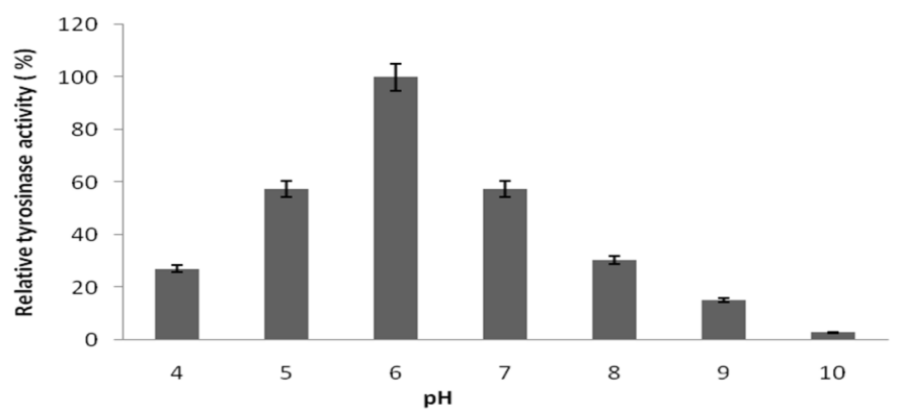

Figure 1 Effect of $\mathrm{pH}$ on the tyrosinase activity of the crude extract of P.ostreatus. Data were obtained as mean value of optical density. Assays were done at $35^{\circ} \mathrm{C}$, the activity of the sample was incubated in $100 \mathrm{mM}$ acetate buffer at $(4.0-5.0 \mathrm{pH}), 100 \mathrm{mM}$ phosphate buffer at $(6.0-8.0 \mathrm{pH})$ and $100 \mathrm{mM}$ Tris-HC buffer at $(9.0-10 \mathrm{pH})$. The optimum activity of the sample at $\mathrm{pH} 6.0$ was taken as $100 \%$

Temperature profile showed that the enzyme had optimum activity at $35^{\circ} \mathrm{C}$ (Figure. 2) which is similar to those reported earlier. The optimum temperature for tyrosinase from Pycnoporus sanguineus has been reported to be $25^{\circ} \mathrm{C}$, and 25 to $40^{\circ} \mathrm{C}$ for Agaricus bisporus (Xu et al., 2011). In contrast to the data of the present study, it has been found that the optimum temperature of tyrosinase from Solenum melongena was high as $65^{\circ} \mathrm{C}$ (Lee et al., 1997).

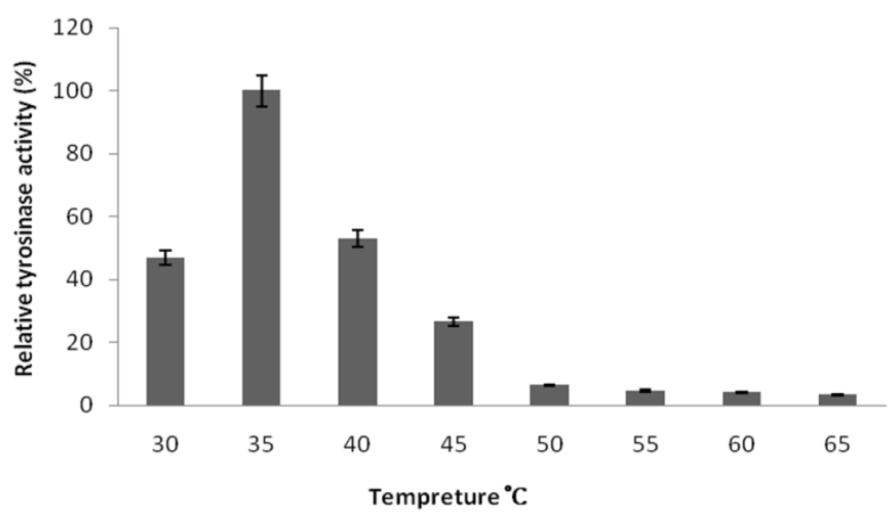

Figure 2 Effect of temperature on the tyrosinase activity of the crude extract prepared from P. ostreatus. Data were obtained as mean value of optical density. Assays were done in potassium phosphate buffer $(100 \mathrm{mM}, \mathrm{pH}=6.0)$. The optimum activity of the sample incubated at $35^{\circ} \mathrm{C}$ was taken as $100 \%$

Based on the Lineweaver-Burk analysis, the $\mathrm{Km}$ and $\operatorname{Vmax}$ values of tyrosinase from $P$. ostreatus were $0.119 \mathrm{mM}$ and $2.97 \mathrm{mg}$, respectively (Figure.3). This indicates the high affinity of the enzyme to the substrate. Tyrosinase of different sources has different substrate affinities and probably plays different physiological roles in the enzyme activity. Higher $K m$ values $(1.9 \mathrm{mM}$ and 0.9 $\mathrm{mM}$ ) for tyrosinase from L. boryana and Pycnoporus species, respectively, have been reported (Faria et al., 2007; Halaouli et al., 2005). On the other hand, a lower $K m$ value $(0.35 \mathrm{mM})$ was obtained for tyrosinase from Bacilus megaterium (Shuster et al., 2009).

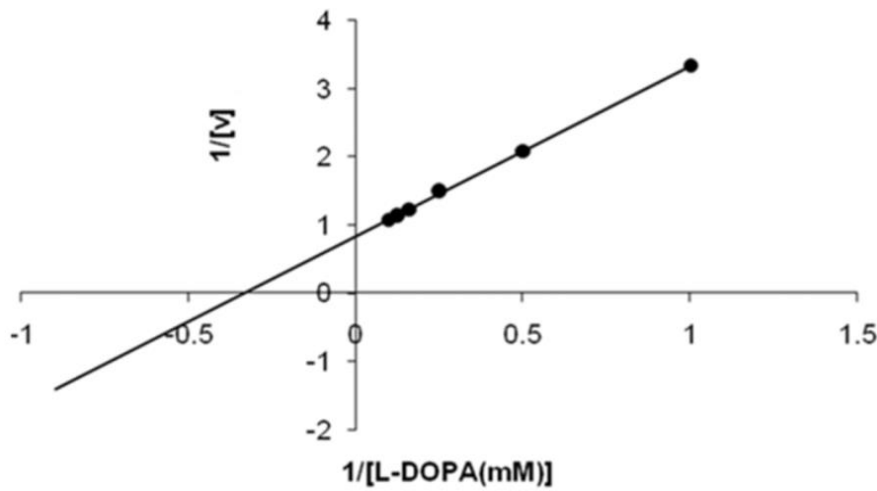

Figure 3 Lineweaver-Burk plot of $P$. ostreatus tyrosinase. Data were obtained as mean value of $1 /$ [V], inverse of the increaser of optical density at $475 \mathrm{~nm}$ per $\mathrm{min}$. (OD475/min/mg), of three independent tests with different concentrations of L-DOPA as a substrate

\section{Partial purification of Tyrosinase}

The partial purification of tyrosinase crude extracts of P.ostreatus was achieved by $75 \%$ ammonium sulfate precipitation. The total protein decreased from 274 to $50.0 \mathrm{mg}$ in ammonium sulfate precipitation steps, whereas the specific activity of tyrosinase was measured to $46.4 \mathrm{U} / \mathrm{mg}$ (Table.1). The data reported by other researchers regarding the specific activity of tyrosinase, isolated from different species of mushrooms was found to be highly variable, Trifolium pretense as 5.94 U/mg (Schmitz et al., 2008), Crocus sativus as 27 U/mg (Saiedian et al., 2007), Agaricus bisporus as $30 \mathrm{U} / \mathrm{mg}$ (Shi et al., 2002), Pycnoporus sanguineus as 30.2 $\mathrm{U} / \mathrm{mg}$ (Halaouli et al., 2005) and Aeromonas media as $34 \mathrm{U} / \mathrm{mg}$ (Wan et al., 2009). The present study indicated that the specific activity of tyrosinase from P.ostreatus, was found to be higher than the earlier reports. Mushroom contains a considerable amount of various phenolic compounds, which are readily oxidized during the homogenizing process. By foremost oxidation and successive polymerization of the phenolic content of the mushroom extract, macromolecules of melanin are formed. Separating the unwanted melanin from the protein content of the extract is the first, or probably the most, important task during the mushroom tyrosinase purification. Though an organic solvent can prevent the melanin formation to a great amount, but increases the proteins denaturation risk. It is required to reduce the salt content of a protein mixture before loading it onto an ion-exchange column. Therefore, the collected proteins by $75 \%$ saturated ammonium sulfate were chromatographed on a Sephadex G-100 column. Doing so, not only ammonium sulfate was replaced by buffer, but also large amount of phenolic compounds were washed down. 
Table 1 Purification of tyrosinase from extracted mushroom

\begin{tabular}{|c|c|c|c|c|c|c|c|}
\hline Fractions & $\begin{array}{c}\text { Volume } \\
\mathrm{mL}\end{array}$ & $\begin{array}{c}\text { Total } \\
\text { Protein (mg) }\end{array}$ & $\begin{array}{c}\text { Activity } \\
\text { (Units) }\end{array}$ & $\begin{array}{c}\text { Total activity } \\
\text { (Units) }\end{array}$ & $\begin{array}{c}\text { Specific } \\
\text { activity } \\
\text { U/mg }\end{array}$ & Purification Fold & $\begin{array}{c}\text { Yield } \\
(\%)\end{array}$ \\
\hline Crude extract & 300 & 274 & 1.48 & 777 & 2.83 & 1 & 100 \\
\hline Ammonium sulphate precipitate & 100 & 50.8 & 2.03 & 503 & 9.90 & 3.49 & 64.7 \\
\hline Gel filtration G100 Column & 45 & 8.5 & 4.31 & 194 & 22.8 & 8.05 & 24.9 \\
\hline DEAE-Cellulose Column & 20 & 3.4 & 7.9 & 158 & 46.4 & 16.39 & 20.3 \\
\hline
\end{tabular}

\section{DEAE Diethylaminoethyle}

The Sephadex G-100 gel filtration column chromatography showed that the profile fractions contained different protein molecules, although only one peak showed activity for tyrosinase from P.ostreatus (Figure.4). Also, the purification of the enzyme rich fractions of the Sephadex G-100 gel filtration on the DEAE cellulose column is shown in (Figure.5). A sharp distinctive peak of tyrosinase activity, indicates the purity of extraction with only one protein peak was obtained. It is possible to omit both the phenolics and melanin impurities from the protein mixture at this stage. Since a matter of fact, melanin shows very high affinity for DEAE cellulose polymer. Hence, the mixture of protein and melanin is loaded on the DEAE cellulose column and successively washed by molar solution of $\mathrm{NaCl}$. Here, tyrosinase is the only protein which is released on elution.

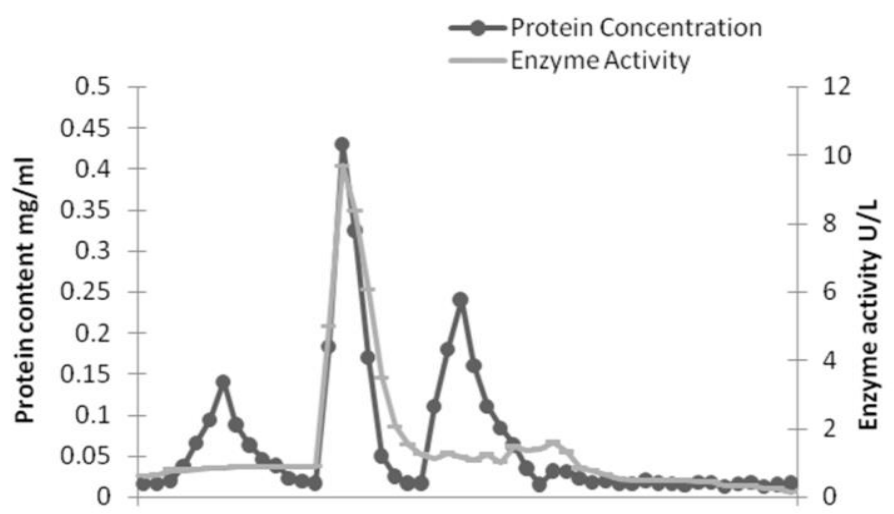

$144 \quad 71013161922252831343740434649$ No of fraction

Figure 4 First gel filtration chromatography of tyrosinase. The dialyzed ammonium sulfate precipitate was chromatographed on Sephadex G-100. Total protein was monitored at $280 \mathrm{~nm}$. The fractions were assayed for the tyrosinase activity

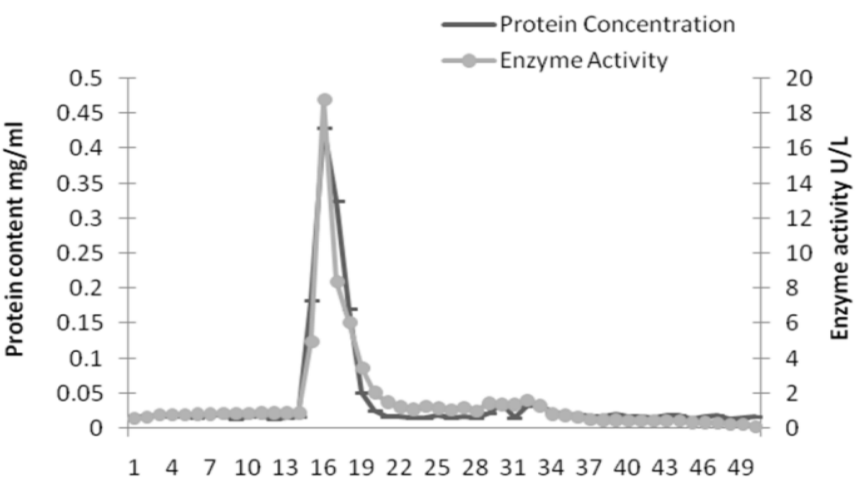

No of fraction

Figure 5 Second DEAE-Cellulose chromatography of tyrosinase. The first gel filtration G-100 collected fraction was applied to DEAE-Cellulose. Total protein was monitored at $280 \mathrm{~nm}$ and the fractions were assayed for tyrosinase activity
In the present study, a sharp distinctive peak of tyrosinase activity, indicates the purity of extraction with only one protein peak was obtained. SDS PAGE of the enzyme preparation from different purification steps showed that the resolved electrophoretic bands progressively improved from the crude extract to the final steps of the DEAE Cellulose column with a distinctive band of $75 \mathrm{kDa}$ and several minor proteins smaller than $45 \mathrm{kDa}$ were observed but not clearly visible in the scanned gels. (Figure.6).The molecular weight of tyrosinase was found to be highly variable with various studies conducted by other researchers. Similar results have been reported from the fungal tyrosinase of Aspergilus orizae being $67 \mathrm{kDa}$ (Ichishima et al., 1984), of Lentinula edodes being $70 \mathrm{kDa}$ (Kanda et al., 1996) and of the Protabella mushroomas $70 \mathrm{kDa}$ (Fan and Flurkey, 2004) Comparative assessment on the molecular weight of some plant tyrosinases lies approximately between 40 to $65 \mathrm{kDa}$ as in Brassica oleracea (Gawlik $\boldsymbol{e t}$ al., 2007) and Trifolium pretense (Schmitz et al., 2008). These reports have simiarity with the present study.The purification scheme removed most of the major proteins with lower molecular weight found in the crude extracts (Figure. 6 lane A). One major stained banks of protein were present in the final sample along with a protein with less staining intensity (Figure 6 lane E). The estimated size of the major bands was approximately $75 \mathrm{kDa}$. The minor protein bands were estimated to have a size of 45 and $50 \mathrm{kDa}$. Several minor proteins smaller than 45 $\mathrm{kDa}$ were present but not readily visible in the scanned gels. We assume that the bands in the $42 \mathrm{kDa}$ are the active proteolyzed forms of tyrosinase that many other investigators have observed (Wicherse et al., 1996; Gerritsen et al., 1994; Zhang et al., 1999). The minor band 45 and $50 \mathrm{kDa}$ could be the latent tyrosinase that is known to have a higher molecular weight (Espin and Wichers, 1999; Espin et al., 2000). The tyrosinase extracted from $P$. ostreatus was observed to have higher activity at a alkaline $\mathrm{pH}$, make it extremely valuable for different therapeutic and industrial applications. In the further experimentation, development of cross-linked biopolymers would be done to modify the structural properties of the food matrix.

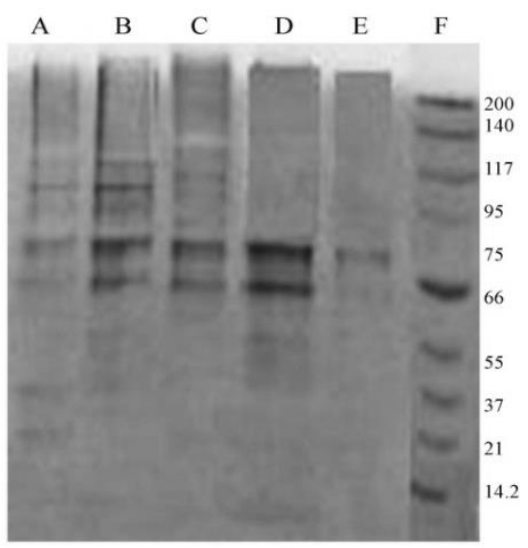

Figure 6 Polyacrylamide gel electrophoresis of tyrosinase from $P$. ostreatus, lane A, crude extract; lane B, ammonium sulfate fraction; lane C Dialysis, lane D Sephadex G-100 gel filtration fraction; lane E, DEAE Cellulose fraction; lane F standard protein of different molecular weight. Arrow indicates location of tyrosinase approximately $\sim 75 \mathrm{kDa}$.

\section{CONCLUSION}

There is an increasing demand for various natural enzymes in industries, in spite of their wide acceptance in the global market. Different enzymes are used for hydrolyzing food biopolymers so as to improve product characteristics. 
Tyrosinase constitutes one of the most important groups of commercial enzymes due to its ability to utilize a wide variety of mono- and di-phenolic compounds. In the present work, an initial step is taken to evaluate the industrial potential of a preliminary characterized tyrosinase enzyme of $P$. ostreatus. It is concluded that the purified and characterized tyrosinase from $P$. ostreatus has comparatively better enzyme properties than reported earlier in other sources. The tyrosinase extracted from $P$. ostreatus was observed to have higher activity at a alkaline $\mathrm{pH}$, create an important and different applications in food industry. The enzyme can also be used to produce cross-linked proteins, allowing enzyme biocatalysts to recycle easily and to improve the consistency and texture of proteins. The tyrosinase from P.ostreatus has economic advantage over the commercialy synthesized tyrosinase.

Acknowledgments: The authors are thankful to Peoples University, People's Group, Bhopal for providing laboratory facilities and for granting financial assistance to carry out present research work. and to the Principal and Secretary, Saifia College of Science, Bhopal for encouragement.

\section{REFERENCES}

ALI, A.S., SUltan, T., GAlGUT, M.J., SHARMA, R., MEITEI, V.K., ALI, S.A. 2011 In vitro responses of fish melanophores to lyophilized extracts of Psoralea corylifolia seeds and pure psoralen, Pharmaceutical Biology, 49(4): 422-427. http://dx.doi.org/10.3109/13880209.2010.521164

BUCHERT, J., ERCILI CURA, D., MA, H., GASPARETTI, C., MONOGIOUDI, E., FACCIO, G., MATTINEN, M., BOER, H., PARTANEN, R., SELINHEIMO, E., LANTTO, R. KRUUS, K. 2010. Crosslinking food proteins for improved functionality. Annual Review of Food Science and Technology, 1 ,

113-138. http://dx.doi.org/10.1146/annurev.food.080708.10084

ESPIN, J.C., SOLER-RIVAS, S., WICHERS, H.J. 2000a. Maturation and activation of latent tyrosinase from Agaricus bisporus.International Society Mushroom Science Precede, 35, 15-19.

ESPIN, J.C., WICHERS, H.J. 1999. Activation of a latent mushroom (Agaricus bisporus) tyrosinase isoform by sodium docecyl sulfate (SDS). Kinetic properties of the SDS-activated isoform. Journal of Agriculture Food Chemistry, 47, 3518 3525. http://dx.doi.org/10.1021/jf981275p

FAN Y., FLURKEY, W.H. 2004. Purification and characterization of tyrosinase from gill tissue of Portabella mushroom. Photochemistry, 65, 671-678.

FARIA, R.O., MOURE, V.R., BALMANT, W., ALMEIDA, M.A., KRIEGER, N., AND MITCHELL, D.A. 2007.The tyrosinase produced by Lentinula boryana (Berk \& Mont.)Pegler suffers substrate inhibition by L-DOPA. Food Technology Biotechnology, 45, 334-340. http://dx.doi.org/10.1016/j.phytochem.2004.01.008 GAWLIK, U., SZYMANOWSKA, U., BARANIAK, B. 2007. Characterization of polyphenol oxidase from broccoli (Brassica oleracea var. Botrytis italica) florets. Food chemistry, 105, 1047-1053 http://dx.doi.org/10.1016/i.foodchem.2007.05.012

GERRITSEN, Y.A.M., CHAPELON, C.G.J., WICHERS, H.J. 1994. The low isoelectric point tyrosinase of Agaricus bisporus may be a glycoprotein Phytochemistry, 35, 573-577. http://dx.doi.org/10.1016/s0031-9422(00)90563-6 GOUZI, H., BENMANSOUR, A. 2007. Partial purification and characterization of polyphenol oxidase extracted from Agaricus bisporus.International Joural of Chemical Reactor Engineering, 5, 0000. http://dx.doi.org/10.2202/1542 6580.1445

HAGHBEEN, K., JAZII, F.R., KARKHARE, A.A., BOROJERDI, S.S. 2004 Purification of Tyrosinase from edible mushroom.Iranian Journal of Biotechnology, 2, 189-194.

HALAOULI, S., ASTHER, M., KRUUS, K., GUO, L., HAMDI, M., SIGOILLOT, JC., ASTHER, M., LOMASCOLO, A. 2005. Characterization of a new tyrosinase from Pycnoporus species with high potential for food technological applications. Journal of Applid Microbiology, 98, 332-343. http://dx.doi.org/10.1111/j.1365-2672.2004.02481.x

ICHISHIMA, E., MAEB, H., AMIKURA, T., AND SAKATA, H. 1984. Multiple forms of protyrosinase from Aspergillus oryzae and their mode of activation at $\mathrm{pH}$ 3.0. Biochemical Biophysical Acta, 786, 25-31. http://dx.doi.org/10.1016/0167-4838(84)90149-3

KANDA, K., SATO, T., ISHII, S., ENEI, H., EJIRI, S. 1996. Purification and properties of tyrosinase isozymes from gill of Lentinus edodes fruiting bodies. $\begin{array}{llll}\text { Bioscience } \quad \text { Biotechnology } \quad \text { Biochemistry, } & \text { 1273-1278 }\end{array}$ http://dx.doi.org/10.1271/bbb.60.1273

KOTANEN, C.N., MOUSSY, F.G., CARRARA, S., GUISEPPI-ELIE, A. 2012, Implantable enzyme amperometric biosensors. Biosensors \& bioelectronics, 35, 14-26. http://dx.doi.org/10.1016/j.bios.2012.03.016

LEE, J.L., KONG, K.H., CHO, S.H. 1997. Purification and characterization of tyrosinase from Solanum melongena .Journal of Biochemistry and Molecular Biology, 30, 150-156.

LOWRY, O.H., ROSEBROUGH, N.J., LEWIS, A., RANDALL, R.J. 1951 Protein measurements with folin phenol reagent. Journal of Biology Chemistry, $193,265-275$.
MONOGIOUDI, E., FACCIO, G., LILLE, M., POUTANEN, K., BUCHERT, J. MATTINEN, M. 2011. Effect of enzymatic crosslinking of $\beta$-casein on proteolysis by pepsin. Food Hydrocolloids, 25, 1, 71-81. http://dx.doi.org/10.1016/j.foodhyd.2010.05.007

MULLER, L.A., RINZ, U., ZRYD, J. P. 1996. Characterization of tyrosinase from Amanita muscaria involved in betalain biosynthesis. Phytochemistry, 42 1511-1515. http://dx.doi.org/10.1016/0031-9422(96)00171-9

SAIEDIAN, S., KEYHANI, E., KEYHANI, J. 2007. Polyphenol oxidase activity in dormant saffron (Crocus sativus L.) corm. Acta Physiologica Plantarum, 29 463-471. http://dx.doi.org/10.1007/s11738-007-0056-Z

SANG, HJ., KYUNG, HK., JONG, U.K., KONG, KH. 2005. Inhibitory Effects on L-Dopa Oxidation of Tyrosinase by Skin-whitening Agents.Bullatin Korean Chemistry, 26, 1135-1137. http://dx.doi.org/10.5012/bkcs.2005.26.7.1135

SELINHEIMO, E., EIDHINM, D., STEFFENSEN, C., NIELSEN, J., LOMASCOLO, A., HALAOULI, S., RECORD, E., BEIRNE, D., BUCHERT, J., AND KRUUS, K. 2007. Comparison of the characteristics of fungal and plan tyrosinases. Journal of Biotechnology, 130, 471-480. http://dx.doi.org/10.1016/j.jbiotec.2007.05.018

SHUSTER, V., FISHMAN, A. 2009 Isolation, Cloning and Characterization of a Tyrosinase with Improved Activity in Organic Solvents from Bacillus megaterium. Molecular Microbiology Biotechnology, 17,188-200 http://dx.doi.org/10.1159/000233506

SCHMITZ, GE., SULLIVAN, M.L., HATFIELD, R.D. 2008. Three polyphenol oxidases from red clover (Trifolium pratense) differ in enzymatic activities and activation properties. Journal of Agriculture Food Chemistry, 56, 272-280. http://dx.doi.org/10.1021/jf072488u

STANIC, D., MONOGIOUDI, E., ERCILI, D., RADOSAVLJEVIC, J., ATANASKOVIC-MARKOVIC, M., VUCKOVIC, O., RAIJA, L., MATTINEN, M., BUCHERT, J. \& CIRKOVIC VELICKOVIC, T. 2010. Digestibility and allergenicity assessment of enzymatically crosslinked betacasein. Molecular Nutrition $\quad \& \quad$ Food Research, 54, 9, 1273-1284. http://dx.doi.org/10.1002/mnfr.200900184

SUNG, C.K., CHO, S.H. 1992. The purification and characteristics of tyrosinase from ginger. Journal of Biochemistry Molecular Biology, 25, 564-572.

TANTOUSH, Z., STANIC, D., STOJADINOVIC, M., OGNJENOVIC, J., MIHAJLOVIC, L., ATANASKOVIC- MARKOVIC, M. CIRKOVIC VELICKOVIC, T. 2011. Digestibility and allergenicity of $\beta$ - lactoglobulin following laccase-mediated crosslinking in the presence of sour cherry phenolics. Food Chemistry, $\quad 125, \quad 1, \quad 84-91$ http://dx.doi.org/10.1016/i.foodchem.2010.08.040

VAN DORST, B., MEHTA, J., BEKAERT, K., ROUAH-MARTIN, E., DECOEN W., DUBRUE, P., BLUS R., ROBBEN, J. 2010, Recent advances in recognition elements of food and environmental biosensors: a review. Biosensors \& bioelectronics, 26,4, 1178-94. http://dx.doi.org/10.1016/i.bios.2010.07.033

VÂNIA, P.S., DOS SANTOSA, LÍVIA M.C., SILVAA- ANDREA, M SALGADOA-KAREN, S. 2013 Pereirab application of agaricus bisporus extract for benzoate Sodium detection based on tyrosinase inhibition for Biosensor development. Chemical engineering transactions 32,2. 1831-1836

WAN, X., CHAI, B., LIAO, Y., SU, Y., YE, T., SHEN, P., CHEN, X. 2009. Molecular and biochemical characterization of a distinct tyrosinase involved in melanin production from Aeromonas media.Applied Microbiology Biotechnology, 82, 261-269. http://dx.doi.org/10.1007/s00253-008-1742-5

WICHERS, H.J., GERRITSEN, Y.A.M., CHAPELON, C.G.J. 1996. Tyrosinase isoforms from the fruit bodies of Agaricus bisporus. Phytochemisty, 43, 333-337. http://dx.doi.org/10.1016/0031-9422(96)00309-3

XU, D.Y., YANG, Y., YANG, Z., 2011. Activity and stability of cross-linked tyrosinase aggregates in aqueous and non aqueous media. Journal of Biotechnology, 152, 30-36. http://dx.doi.org/10.1016/j.jbiotec.2011.01.014

ZHANG, X.D., VAN, LEEUWEN, J., WICHERS, H.J., FLURKEY, W.H. 1999 Characterization of tyrosinase from the cap flesh of portabella mushrooms. Journal of Agriculture Food Chemistry, 47, 374-378 http://dx.doi.org/10.1021/jf980874t

ZAIDI, K.U., ALI, S.A., ALI, A.S., NAAZ, I. 2014. Microbial Tyrosinase Promising Enzymes for Pharmaceutical, Food Bioprocessing, and Environmenta Industry. Biochemistry Research International, 2014, 1-16. http://dx.doi.org/10.1155/2014/854687

ZAIDI, K.U., MANI, A., ALI, S.A., ALI, A.S. 2013.Evaluation of Tyrosinase Producing Endophytic Fungi from Calotropis gigantea, Azadirachta indica, Ocimum tenuiflorum and Lantana camara. Annual Review \& Research in Biology,3(4): 389-396.

ZAIDI, K,U., ALI, S.A., ALI, A.S. 2014 Purification and Characterization of Melanogenic Enzyme Tyrosinase from button mushroom. Enzyme Res 2014: 16. http://dx.doi.org/10.1155/2014/120739 